\title{
STUDY OF INFLUENCE OF FREEZING-DEFROSTING ON THERMOPHYSICAL PROPERTIES OF MEAT SYSTEMS
}

\author{
Marina Yancheva \\ Department of Meat Technology \\ Kharkiv State University of Food Technologies and Trade \\ 333 Klochkivska str., Kharkiv, Ukraine, 61051 \\ ya.marina11@gmail.com \\ Olena Dromenko \\ Department of Meat Technology \\ Kharkiv State University of Food Technologies and Trade \\ 333 Klochkivska str., Kharkiv, Ukraine, 61051 \\ elena.dromenko@gmail.com \\ Vladimir Potapov \\ Department of Trade and refrigeration equipment \\ Kharkiv State University of Food Technologies and Trade \\ 333 Klochkivska str., Kharkiv, Ukraine, 61051 \\ potapov@bigmir.net \\ Olga Grinchenko \\ Department of Food Technology \\ Kharkiv State University of Food Technologies and Trade \\ 333 Klochkivska str., Kharkiv, Ukraine, 61051 \\ grinoly@gmail.com \\ Tetiana Zhelieva \\ Department of Meat Technology \\ Kharkiv State University of Food Technologies and Trade \\ 333 Klochkivska str., Kharkiv, Ukraine, 61051 \\ sts512@ukr.net
}

\begin{abstract}
There were studied thermophysical properties of meat systems, based on comminuted beef with different chemical compositions in the process of freezing-defrosting. It was demonstrated, that the morphological base of meat (the ratio of muscular, connective and fatty tissues) and its chemical composition essentially influence thermophysical properties in the process of freezing-defrosting. It was revealed, that under conditions of realization of freezing-defrosting cycle with the fat mass share increase, the temperature increase of the maximal speed of crystal creation, decrease of the cryoscopic temperature interval, increase of the share of moisture that changes its aggregate state in the cryoscopic temperature interval, increase of specific heat of the phase transfer in the cryoscopic temperature interval are observed in a meat system. The type of changes of the cryoscopic temperature interval allows to detect that fat essentially influences the process of freezing-defrosting. The realized studies of comparison of thermodys namic changes in meat systems at refrigerator processing allowed to determine the strategy of saving meat systems' stability that is in providing meat proteins' colloid stability and renewing initial properties of the meat raw material after storage and defrosting.

Keywords: thermophysical properties, meat systems, crystal creation, cryoscopic interval, freezing-defrosting.

(c)Marina Yancheva, Olena Dromenko, Vladimir Potapov,

\section{Introduction}

Main technological factors of food systems' freezing testify that the important things in the process of their production are: reversibility of properties under conditions of the low-temperature 
processing, stabilization of the colloid state of proteins of a meat system, decrease of moisture mobility, formation of fine ice crystals and decrease of their pressure on morphological masses of the raw material [1]. Despite the presence of the great amount of information about the freezf ing-defrosting influence on the meat raw material, including, the comminuted one, in the literature, absolute values of its physical-chemical, thermo-physical and other parameters vary within wide limits (as a result of using the raw material with the individual chemical composition and different freezing methods) and cannot be used for determining the strategy of their stability guaranteeing without the experimental determination.

\section{Review of the problem state}

At freezing food products, there take place irreversible negative changes, connected with phase and phase-structural transformations as a result of crystal creation of the water phase [2, 3]. Ice crystals, appeared in the inter-cellular space results in disruption of muscular fibers, denaturation and aggregation of proteins that then negatively influence functional-technological properties of defrosted meat and is manifested, first of all in essential losses of meat juice and decrease of consumption characteristics of ready products $[4,5]$. The negative influence of freezing is mainly revealed at the low-temperature processing of semi-products of comminuted meat, because at comminution as a result of mechanic destruction of the meat cellular structure, the muscular tissue loses integrity, the system of capillaries and cellular membranes is destructed, the additional amount of moisture is excreted at the expanse of decreasing osmotically- and capillary-bound moisture [6, 7].

For producing frozen meat products of the high quality, from the technological point of view, it is important to provide conditions for creating fine evenly distributed ice crystals for providing integrity of meat muscular fibers. Ice crystals' formation in such complicated system as meat depends not only on the freezing speed, but also on physical-chemical and structural properties of the tissue (the ratio of water, fat, muscular and connective tissue) [8].

Water transformation in ice at freezing is accompanied by moisture migration and changes of thermo-physical and mechanical properties. The change of the water phase state is the main factor that causes deceleration of undesirable diffuse, chemical, biochemical and microbiological processes in food products at their freezing $[9,10]$.

As it is known, the equilibrium energy of the bond (E) of moisture in a frozen product, acr cording to D. G. Riutov's equation depends on its temperature:

$$
\mathrm{E}=\Delta \mathrm{H}_{\mathrm{cr}} \frac{-\mathrm{t}}{273,15}, \mathrm{cr}
$$

where $\Delta \mathrm{H}_{\mathrm{cr}}-$ specific heat of water transformation in ice, $\mathrm{kJ} / \mathrm{kg} ; \mathrm{t}$ - final (equilibrium) temperature of a product for the given bond energy, ${ }^{\circ} \mathrm{C}$.

As it can be seen from this equation, the character of the moisture bond can be influenced by the value $\Delta \mathrm{H}_{\mathrm{cr}}$ - specific heat of water transformation in ice that changes in a food product due to the presence of dissolved substances. Thus, the decrease of heat of water transformation in a product results in the decrease of the temperature that the full freezing out of moisture takes place at, and, as a result, increase of cryoprotective properties of a product.

It is also known, that according to the second Raul's law, the concentration increase of soluble substances decreases the cryoscopic temperature in the direct proportion to the molal concentration:

$$
\Delta \mathrm{t}_{\mathrm{cr}}=\mathrm{Kn}_{\mu}, \mathrm{K} \mathrm{cr}
$$

where $\mathrm{n}_{\mu}$ - molal concentration, $\mathrm{mol} / \mathrm{kg}, \mathrm{K}$ - cryoscopic constant, $\mathrm{K} /(\mathrm{mol} / \mathrm{kg})$.

Thus, the concentration increase of dissolved substances in a meat system also results in the decrease of the cryoscopic temperature that conditions the beginning of the crystallization process and crystals' size. The less this temperature is, the less ice crystals and coefficient of diffusion 
through cellular membranes that is a positive factor from the point of view of saving consumption properties of a frozen raw material.

The initial data for most methods of the thermal analysis are thermograms - temperature dependencies of a studied sample on a certain physical parameter [11]. Methods of measuring thermophysical characteristics, thermal effects of phase transfers, chemical and biochemical reactions are built on these dependencies. The essential limitation of most methods is a requirement as to stability of physical characteristics, absence of thermal effects of another nature, correct geometry of a sample, time interval of measuring and so on. Most these limitations don't work in the experiment for moist disperse systems including meat products that results in the essential dispersion of thermophysical characteristics, obtained by different methods and by different researchers.

So, for revealing and comparing thermodynamic changes at freezing-defrosting, it is necessary to realize the objective evaluation of thermophysical processes' course in meat systems at freezing-defrosting, especially, to determine the effective specific thermal capacity by thermograms of freezing-defrosting. It allows to determine the strategy of providing stability of meat systems that is in providing meat proteins' colloid stability and renewing initial properties of the meat raw material after storage and defrosting.

\section{Materials and Methods}

Comminuted meat systems of beef with different chemical compositions (table 1) were chosen as research objects as most model from the point of view of the influence of low temperatures on proteins of the muscular tissue.

Table 1

The general chemical composition of the studied meat comminuted systems

\begin{tabular}{|c|c|c|c|}
\hline \multirow{2}{*}{ Parameters } & \multicolumn{3}{|c|}{ Samples } \\
\hline & 1 & 2 & 3 \\
\hline \multicolumn{4}{|c|}{ Before freezing } \\
\hline Mass share of moisture, $\%$ & $73,4 \pm 0,2$ & $71,0 \pm 0,2$ & $68,9 \pm 0,2$ \\
\hline Mass share of protein, $\%$ & $19,8 \pm 0,2$ & $18,7 \pm 0,2$ & $17,3 \pm 0,2$ \\
\hline Mass share of fat, $\%$ & $5,8 \pm 0,1$ & $9,5 \pm 0,1$ & $13,2 \pm 0,1$ \\
\hline Mass share of mineral substances, $\%$ & $1,00 \pm 0,02$ & $0,80 \pm 0,04$ & $0,60 \pm 0,03$ \\
\hline $\mathrm{pH}$ & $5,9 \pm 0,1$ & $5,9 \pm 0,1$ & $5,9 \pm 0,1$ \\
\hline \multicolumn{4}{|c|}{ After freezing-defrosting } \\
\hline Mass share of moisture, $\%$ & $71,9 \pm 0,2$ & $69,9 \pm 0,2$ & $68,2 \pm 0,2$ \\
\hline Mass share of protein, $\%$ & $20,3 \pm 0,2$ & $19,0 \pm 0,2$ & $17,5 \pm 0,2$ \\
\hline Mass share of fat, $\%$ & $6,6 \pm 0,1$ & $10,2 \pm 0,1$ & $13,6 \pm 0,1$ \\
\hline Mass share of mineral substances, $\%$ & $1,20 \pm 0,02$ & $0,90 \pm 0,04$ & $0,70 \pm 0,03$ \\
\hline $\mathrm{pH}$ & $5,9 \pm 0,1$ & $5,9 \pm 0,1$ & $5,9 \pm 0,1$ \\
\hline
\end{tabular}

For preparing comminuted meat systems, there was used beef, cooled according to SSTU 6030:2008, which safety parameters corresponded to P 1.1 «Obligatory minimal list of studies of an animal or vegetable raw material, mixed fodder raw material, mixed fodders, vitamin preparations and other, that must be realized in state laboratories of veterinary medicine for obtaining a veterinary certificate". Stability of the chemical composition of studied samples is achieved and provided within the set tasks by using the same type of the meat raw material for each experiment.

Comminuted meat systems were received by beef comminution by a meat chopper with the diameter of grid orifices $(2 \ldots 5) \times 10^{-3} \mathrm{~m}$. Samples in the form of low cylinder with the diameter $5 \times 10^{-2} \mathrm{~m}$ and height $1 \times 10^{-2} \mathrm{~m}$ were formed of the comminuted raw material. Thermocouples were placed in several points of a sample: in the center, on the upper and low surface and also above a sample in a cold store. 
The study of thermophysical characteristics of comminuted meat systems were realized on a laboratory experimental stand within the temperature interval $-20 \ldots+20^{\circ} \mathrm{C}$ (optimal temperature interval for getting informational parameters of the temperature dependence of effective thermal capacity of the studied systems), equipped by a multi-functional eight-channel measurer-regulator OWEN TPM 138-R with an automatic transformer of interfaces OWEN AS 4, produced in Ukraine (Fig. 1). The temperature of samples was measured automatically with discreteness $\Delta \tau=1 \times 60 \mathrm{~s}$.

The results processing was realized using software Owen Process Manager ("OWEN" coms pany, city Kharkiv, Ukraine) by building thermograms in the studied temperature interval.

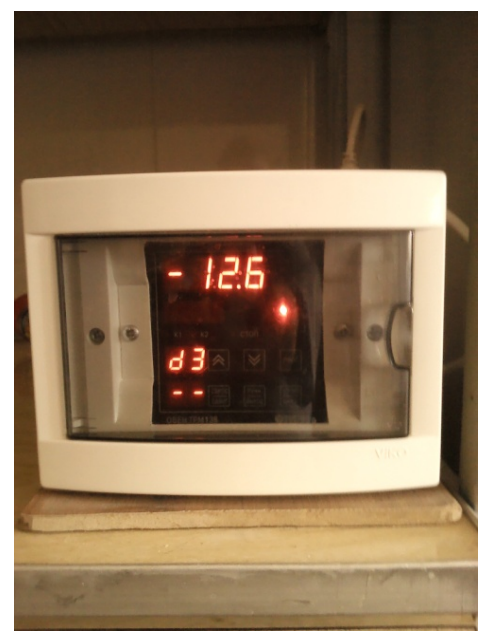

Fig. 1. General look of the multi-functional eight-channel measurer-regulator OWEN TPM 138-R with an automatic transformer of interfaces OWEN AS 4

The method of the analysis of kinetics of transfer phenomena in unbalanced thermodynamic systems was used for analyzing thermograms of freezing-defrosting [12]. This method is based on an approximate solution of the extreme problem about thermal exchange in a case of arbitrary geometry of a body and heterogenic extreme conditions.

Effective enthalpy and effective specific thermal capacity are physical values that include all types of thermal effects that take place in the process of freezing-defrosting of a system: temperature changes of thermal capacity, heat of phase transfers, heat of chemical and biochemical reactions. The analysis of thermograms was realized with taking into account these values.

The informational parameters were obtained by temperature dependencies of effective thermal capacity:

$\mathrm{T}_{\mathrm{cr}}-$ cryoscopic temperature, ${ }^{\circ} \mathrm{C}$;

$\Delta \mathrm{T}_{\mathrm{cr}}-$ cryoscopic temperature interval, ${ }^{\circ} \mathrm{C}$;

$\Delta \mathrm{H}_{\mathrm{cr}}-$ specific heat of the phase transfer in the cryoscopic temperature interval, $\mathrm{J} / \mathrm{K}$;

$\Delta \mathrm{H}$ - enthalpy change in the temperature interval $(\Delta \mathrm{T})$ of the measured sample, $\Delta \mathrm{T}, \mathrm{J} / \mathrm{K}$.

The typical peak of effective thermal capacity corresponds to the water-ice phase transfer, its maximum position fixes the cryoscopic temperature of the system. The peak width near the base determines the cryoscopc temperature interval of the beginning and end of the phase transfer, area under the phase transfer peak - specific heat of the phase transfer in the cryoscopic temperature interval.

Taking into account that

$$
\Delta \mathrm{H}_{\text {кр }}=\mathrm{L}_{\omega} \Delta \omega, \mathrm{cr},
$$

where $\mathrm{L}_{\omega}$ - specific heat of the water-ice phase transfer, $335 \mathrm{~kJ} / \mathrm{kg} ; \Delta \omega$ - moisture share that changes its aggregate state in the cryoscopic temperature interval (amount of frozen out of melt moisture), calculated by the formula: 


$$
\Delta \mathrm{H}_{\mathrm{cr}}=\mathrm{L}_{\omega} \Delta \omega, \mathrm{cr}
$$

The enthalpy change $\Delta \mathrm{H}$ was determined by the area under the whole curve of effective specific thermal capacity in the studied temperature diapason.

\section{Results}

The experimental data testified that the curves of freezing-defrosting of samples (1...3) have the same look, but different absolute values. Thus, despite the content of fat-raw material in the meat system, the process of its cooling to the cryoscopic temperature is described by practically the same curves. Three stages can be separated at freezing.

At the first stage of cooling of samples from $+15{ }^{\circ} \mathrm{C}$ to $+1{ }^{\circ} \mathrm{C}$ the temperature decrease of samples takes place proportionally to the amount of work for heat taking. At the second stage the temperature of samples decreases from $+1{ }^{\circ} \mathrm{C}$ to $-(1,2 \ldots 4,4){ }^{\circ} \mathrm{C}$, overcooling of the system and crystallization of $70 \%$ of the liquid phase of a product take place. At the third stage the addia tional freezing of samples to the temperature $-20{ }^{\circ} \mathrm{C}$ takes place, at that there is no new crystals, already formed crystals grow. The temperature decrease takes place proportionally to the work for heat taking.

The Fig. 2 presents the temperature dependencies of effective specific thermal capacity of three samples of meat systems and fat-raw material at freezing-defrosting, Table 2 presents their information parameters. The analysis of the obtained data (Fig. 2 and Table 2 ) allows to state that the freezing-defrosting process is irreversible. All temperature dependencies of effective thermal capacity change, but the type of these changes is individual.

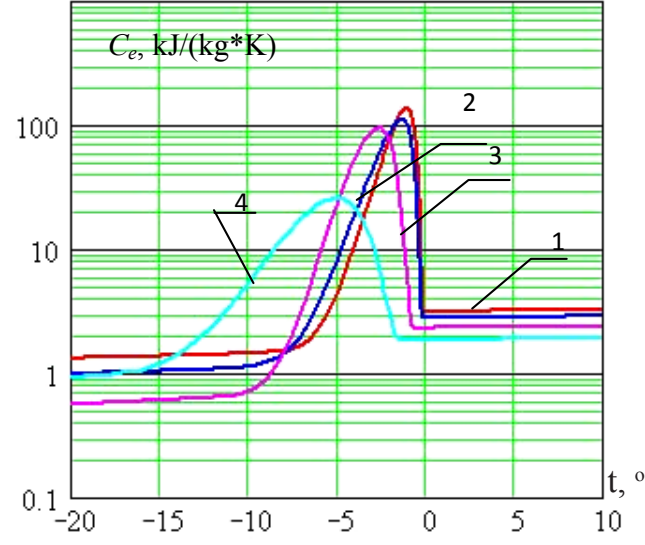

a) freezing

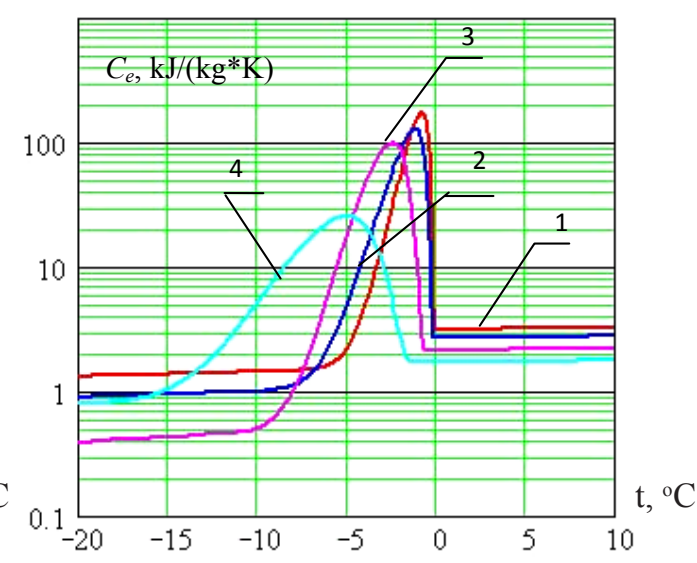

b) defrosting $\mathrm{kJ} /\left(\mathrm{kg}^{*} \mathrm{~K}\right)$

Fig. 2. Temperature dependencies of effective thermal capacity of meat comminuted systems at the fat content, \%: $1-5,8 ; 2-9,5 ; 3-13,2 ; 4-94,0$ (comminuted fat-raw material): $a$ - before freezing; $b$ - after freezing-defrosting

It was established, that the temperature of the maximal speed of comminuted beef system's crystal creation (at freezing) are within the interval $-(1,1 \ldots 2,7){ }^{\circ} \mathrm{C}$. The increase of the cryoscopic temperature interval $(\Delta \mathrm{Tcr})$ is observed for all meat systems with the increased fat component.

The type of the change of the cryoscopic temperature interval allows to determine that fat essentially influences the freezing-defrosting process.

The minimal value of the cryoscopic temperature interval $\left(\Delta \mathrm{Tcr}=3,2^{\circ} \mathrm{C}\right)$ is fixed for sample 1 , the maximal value $\left(\Delta \mathrm{Tcr}=4,4{ }^{\circ} \mathrm{C}\right)$ - is typical for the comminuted beef systems at the fat content $13,2 \pm 0,1 \%$ (sample 3 ). At increasing the share of the fat component, all studied meat systems get the increased value of the cryoscopic interval and decreased specific heat of the phase transfer that fully corresponds to existent literary data about the fat influence on the freezing process. 
Table 2

Parameters of the temperature dependence of effective specific thermal capacity of comminuted meat systems

\begin{tabular}{|c|c|c|c|}
\hline \multirow{2}{*}{ Parameters } & \multicolumn{3}{|c|}{ Samples } \\
\hline & 1 & 2 & 3 \\
\hline \multicolumn{4}{|l|}{ At freezing } \\
\hline Temperature of maximal speed of crystal creation, $\mathrm{T}_{\mathrm{cr}}{ }^{\circ} \mathrm{C}$ & $-1,1$ & $-1,4$ & $-2,7$ \\
\hline Cryoscopic temperature interval, $\Delta \mathrm{T}_{\mathrm{cr}},{ }^{\circ} \mathrm{C}$ & 3,2 & 3,9 & 4,4 \\
\hline Specific heat of phase transfer in the cryoscopic temperature interval, $\Delta \mathrm{H}_{\mathrm{cr}}, \mathrm{kJ} / \mathrm{K}$ & 142 & 126 & 105 \\
\hline Moisture share that changes its aggregate state in the cryoscopic temperature interval, $\Delta \omega$ & 0,27 & 0,24 & 0,20 \\
\hline \multicolumn{4}{|l|}{ At defrosting } \\
\hline Temperature of the maximal melting speed, $\mathrm{T}_{\text {melt }}{ }^{\circ} \mathrm{C}$ & $-0,8$ & $-1,2$ & $-2,5$ \\
\hline Cryoscopic temperature interval, $\Delta \mathrm{T}_{\mathrm{cr}},{ }^{\circ} \mathrm{C}$ & 2,5 & 3,4 & 4,2 \\
\hline Specific heat of phase transfer in the cryoscopic temperature interval, $\Delta \mathrm{H}_{\mathrm{cr}}, \mathrm{kJ} / \mathrm{K}$ & 172 & 147 & 117 \\
\hline Moisture share that changes its aggregate state in the cryoscopic temperature interval, $\Delta \omega$ & 0,35 & 0,30 & 0,24 \\
\hline
\end{tabular}

Note: samples 1, 2, 3, correspond to the samples in Table 1, $n=5, P \geq 0,95$

The comparative analysis of thermophysical characteristics of comminuted beef systems with fat-raw material in the freezing-defrosting cycle allows to make the following conclusions. At defrosting all samples demonstrate the increase of the temperature of the maximal speed of crystal creation, decrease of the cryoscopic temperature interval. At that the fat amount increase decreases the change of these parameters. Thus, in samples 2 and $3 \mathrm{Tcr}$ increases by $14 \%$ and $7 \%$ respectively (for the control by $27 \%$ ); $\Delta T c r$ - decreases by $13 \%$ and $15 \%$ respectively (for the control by $22 \%$ ). The amount of specific heat of the phase transfer in the cryoscopic temperature interval has the same tendency: decrease in $(1,4 \ldots 1,6)$ times with increasing the fat component in the system. At defrosting the moisture share $(\Delta \omega)$ that changes its aggregate state increases in the cryoscopic temperature interval together with specific heat of the phase transfer. At the fat component share increase in the meat system from $5,8 \pm 0,1 \%$ to $13,2 \pm 0,1 \%$ this index increases by $(17 . .20) \%$ respectively (for the control - by $23 \%$ ).

The type of the temperature dependence of effective specific thermal capacity of fat-raw material (Fig. 4) testifies to the absence of the evident phase transfer. Structural changes in fat are observed in the whole studied temperature diapason that testifies to the main share of bound moisture in it. It is proved by the low value of temperature, at which the maximum thermal effect at freezing of fat-raw material $\left(-5,1^{\circ} \mathrm{C}\right)$ and at defrosting $(-3,5)$ is observed.

In general it was revealed, that under conditions of the freezing-defrosting cycle with the fat mass share increase, the increase of the temperature of the maximal speed of crystal creation by (7...14) \%, decrease of the cryoscopic temperature interval by $(13 . .15) \%$, increase of the moisture share, that changes its aggregate state in the cryoscopic temperature interval, by (20...25) \%, increase of specific heat of the phase transfer in the cryoscopic temperature interval by (17...20) \% are observed in the meat system.

This approach fully allows to determine reversibility of the process, systems' ability to renew their initial properties in freezing-defrosting cycles. Comparing with other methods, we must accent the duration of this experiment, because systems are studied under conditions of real time of freezing, storage and further defrosting of samples with continuous taking indication of devices. 


\section{Conclusions}

There were generalized the experimental data of the study of the influence of freezing-defrosting on thermophysical properties of meat systems. It was proved, that the freezing-defrosting process is irreversible. All parameters of the temperature dependence of effective thermal capacity change, but the type of these changes is individual.

The obtained complex of information parameters demonstrated that the morphological construction of meat and its chemical composition essentially influence thermophysical parameters of meat systems in the freezing-defrosting process. Thus, the temperature of the maximal speed of crystal creation increases in all samples at defrosting. The cryoscopic temperature interval decreases. At increasing the fat amount, these parameters change less that testifies to the influence of fat component on the freezing-defrosting process.

The realized studies of comparison of thermodynamic changes in meat systems at refrigerator processing allowed to determine the strategy of saving meat systems' stability that is in providing meat proteins' colloid stability and renewing initial properties of the meat raw material after storage and defrosting.

\section{References}

[1] Evans, Dzh. A. (2010). Zamorozhennye pishhevye produkty: proizvodstvo i realizatsiya. Saint Petersburg: Professiya, 440.

[2] Tuan Pham, Q. (2014). Freezing time formulas for foods with low moisture content, low freezing point and for cryogenic freezing. Journal of Food Engineering, 127, 85-92. doi: 10.1016/j.jfoodeng.2013.12.007

[3] Yancheva, M. O., Hrynchenko, O. O. (2013). Fizyko-khimichni ta biokhimichni osnovy vykorystannia nyzkykh temperatur u tekhnolohiiakh pererobky m'yasa. Prohresyvni tekhnika ta tekhnolohii kharchovykh vyrobnytstv restorannoho hospodarstva i torhivli, 1 (17), 89-97.

[4] Miller, D. K., Kim, H.-W., Lee, Y., Kim, Y. H. B. (2016). Effects of soy hull fibers and freezing on quality attributes of beef patties. Meat Science, 112, 175-176. doi: 10.1016/j.meatsci.2015.08.168

[5] Choe, J.-H., Stuart, A., Kim, Y. H. B. (2016). Effect of different aging temperatures prior to freezing on meat quality attributes of frozen/thawed lamb loins. Meat Science, 116, 158-164. doi: 10.1016/j. meatsci.2016.02.014

[6] Cherniushok, O. A., Fedorov, V. H., Kepko, O. I. (2016). Intensyfikatsiia kholodylnoho obroblennia dribnoshmatkovykh miasoproduktiv. Naukovyi visnyk LNUVMBT imeni S. Z. Hzhytskoho, 18 (1 (65)), 4, 161-166.

[7] Kim, Y. H. B., Liesse, C., Choe, J., Kemp, R. (2015). Effect of different freezing/thawing methods on meat quality characteristics of pre-aged lamb loins. Meat Science, 101, 137-138. doi: 10.1016/j.meatsci.2014.09.090

[8] Yancheva, M. O., Dromenko, O. B., Hrynchenko, O. O., Potapov, V. O., Krainiuk, L. M. (2015). Tekhnolohichni aspekty vyrobnytstva napivfabrykativ m'yasnykh posichenykh zamorozhenykh iz vykorystanniam emulsiinykh system. Kharkiv: KhDUKhT, 178.

[9] Filippov, V. I., Stepanov, A. V. (2015). Ratsional'naya tochnost' opredeleniya teplofizicheskikh kharakteristik pishhevykh produktov v raschetakh tekhnologicheskikh paramerov kholodil'noy obrabotki. Nauchniy zhurnal NIU ITMO, 2, 125-132.

[10] Castro-Giraldez, M., Balaguer, N., Hinarejos, E., Fito, P. J. (2014). Thermodynamic approach of meat freezing process. Innovative Food Science \& Emerging Technologies, 23, 138-145. doi: 10.1016/ j.ifset.2014.03.007

[11] Belozerov, A. G., Berezovskiy, Yu. M., Korolev, I. A., Agafonkina, I. V. (2017). Issledovanie teplofizicheskikh kharakteristik myasa kur. Ptitsa i ptitseprodukty, 1, 18-21.

[12] Potapov, V. A. (2013). Kinetyka yavyshch perenosu v protsesi sushinnia. Deutschland: LAPLAMBERT AcademicPublishing, 319. 